\title{
NOS3 wt Allele
}

National Cancer Institute

\section{Source}

National Cancer Institute. NOS3 wt Allele. NCI Thesaurus. Code C50899.

Human NOS3 wild-type allele is located within 7q36 and is approximately $24 \mathrm{~kb}$ in length.

This allele, which encodes nitric-oxide synthase, endothelial protein, is involved in the biosynthesis of nitric oxide from L-arginine and molecular oxygen. Certain allelic variants of the NOS3 gene are associated with susceptibility to atherosclerosis, pregnancyinduced hypertension, pulmonary hypertension or late-onset Alzheimer's disease. 